\title{
Analysis of Motivation and Learning Outcomes Through Learning Model Using Guided Inquiry and Exe Learning On Redox Reactions in Senior High School Grade X
}

\author{
Lia Nova Sari \\ Departement of Chemistry Education \\ Universitas Negeri Medan \\ Medan, Indonesia \\ *Correspondding authors: lianovasari08@gmail.com \\ Simson Tarigan \\ Departement of Chemistry Education \\ Universitas Negeri Medan \\ Medan, Indonesia \\ Albinus Silalahi \\ Departement of Chemistry Education \\ Universitas Negeri Medan \\ Medan, Indonesia
}

\begin{abstract}
- teachers must effort to actualize the significance of learning. Learning's motivation has a role in students' achievement and performance. This study aims to see the significant differences as well as the correlation between students' learning outcomes that learned with the model of guided inquiry and direct instruction which both use the eXe learning media.
\end{abstract}

Keywords-motivation; achievement; model; inquiry; exe learning

\section{INTRODUCTION}

The student's problem encountered in learning process is the learning gets less attractive and the media is not maximizely developed [1]. One of the efforts to improve teaching learning process in achieving the national goal is to use an interesting learning model which corresponds to Permendikbud No. 65 of 2013 concerning to the standard process which is called as an inquiry learning. Students's science process skills using laboratory based inquiry is higher than the conventional [2]. In accordance with the results of penelitian Suminah [3], inquiry learning in teaching science can improve students' motivation. On the other hand, according to Siregar [4] there are some differences in understanding of students' concepts, scientific attitude and assessment through the implementation of inquiry learning model by the method of discussion. Education as a morality is defined by our actions, and values which they must be taught in character building [5].

\section{LITERATURE REVIEW}

\section{A. Motivation}

Generally, there are several motives which motivate the students to learn. The learning outcomes will be optimal when a correct motivation exists [6]. The design of ARCS (attention, relevance, confidence, satisfaction) motivation [7] consists of four sections, namely: attention, relevance, confidence and satisfaction. Based on statistical studies conducted by Trinora [8] using a simple correlation with a correlation coefficient, it shows a tendency that the more motivation to learn, better or higher students' learning outcomes to get.

\section{B. $\quad$ Model Guided Inquiry}

Inquiry is a process of asking questions and finding out the answers toward the scientific questions [9]. Inquiry learning can certainly train students in proving concepts or principles that have been discussed in learning which will have an impact on imprecision in compiling and formulating conclusions of a practical [10].

\section{C. eXe Learning Media}

EXe (eLearning XHTML editor) is one of an open-source application program that is used for the manufacture of materials based on e-learning. In eXe learning, it can make the type of multiple choice, short answer, true-false, and quizzes that can be used to test the competence of students [11].

\section{METHODOLOGY}

This research is conducted in Senior High School (SMA) Al Hidayah Medan in February-March 2017 consisting of 2 classes, which they are experiments 1 and experiment-2. Independent variables is guided inquiry model and direct instruction which both use $e X e$ Learning, moderator variable is students' motivation, the dependent variable is students' learning outcomes in a redox reaction material. 
This study is experimental, in which there are two classes groups received a different treatment. The first class is taught using a model of guided inquiry with the media $e X e$ Learning and the second class is taught by using direct instruction with the media $e X e$ learning. The data research is learning outcomes and motivation's questionnaire. Learning motivation's score is used to distinguish students who have high and low motivation. Research design can be seen in Table 3.1.

Table 3.1. Design Study

\begin{tabular}{|c|c|c|c|c|}
\hline Group Sample & pretest & Treatment & Motivation & posttest \\
\hline Class Experiment-1 & $\mathrm{T}_{0}$ & $\mathrm{Xe}$ & $\mathrm{ZX}$ & $\mathrm{Tt}$ \\
\hline Class Experiment-2 & $\mathrm{T}_{0}$ & $\mathrm{Ye}$ & $\mathrm{ZY}$ & $\mathrm{Tt}$ \\
\hline
\end{tabular}

Description:

$\mathrm{T}_{0}=$ Initial testing an experimental class- 1 and experimental class-2 (pretest)

$\mathrm{T}_{\mathrm{t}}=$ Tests of experimental class- 1 and experimental class-2 (posttest)

$\mathrm{Xe}=$ learning model inquiry guidedwith media $e X e$ Learning

$\mathrm{Ye}=$ Learning with models of direct instruction with media eXe Learning

$\mathrm{ZX}=$ Student motivation experimental class-1

$\mathrm{ZY}=$ Student motivation experimental class-2

Procedures of the research used in this study, can be seen as the chart in Figure 3.1.

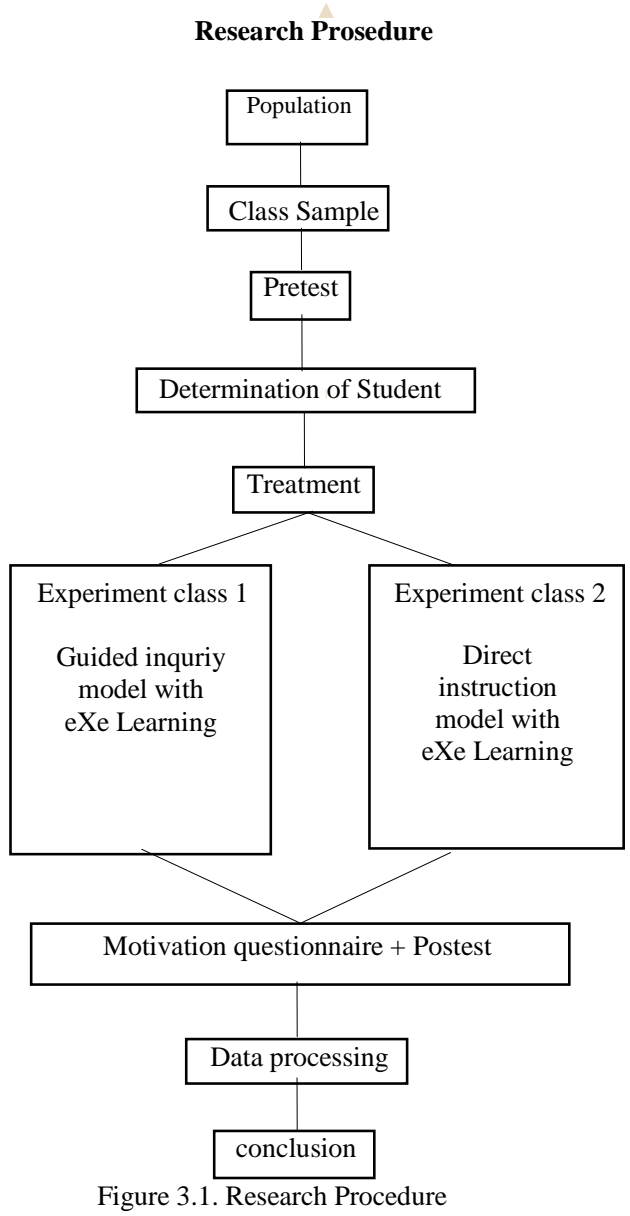

Figure 3.1. Research Procedure

\section{Development Instrument Research}

Developing test instrument mastery of peripherals redox materials and learning motivation's questionnaire can be described by several steps, namely: a test of learning outcomes and students' motivation questionnaire. The students' learning outcomes are firstly tested of the normality and homogeneity. To test the normality used by Statistical Package For The Social Scinces (SPSS) 20.0 with its Kolmogorov-Smirnof or Lilifors, the data can be stated as a normally distributed when the significant probability value (2-sided)> 0.05 significance level [12]. Homogeneity test is performed with Chi Square test, otherwise the data are homogeneous if significant probability value (2-sided)> 0.05 significance level [13].

Analysis of the level of student motivation is done by using questionnaires of student motivation based on Likert scale, namely: SS (strongly agree), S (agree), TS (disagree, STS (strongly disagree). The category of Student motivation is expressed as follows:

Table 3.2. Category Level Student Motivation

\begin{tabular}{|c|c|c|}
\hline No & average & Student Motivation Category \\
\hline 1 & $66-80$ & Very high \\
\hline 2 & $51-65$ & high \\
\hline 3 & $36-50$ & Enough \\
\hline 4 & $21-35$ & Low \\
\hline
\end{tabular}

\section{hypothesis testing}

To test the hypothesis of the study uses SPSS 20 . The data from the two groups of samples analyzed with General Linear Model (GLM) univariate.

$$
\begin{array}{lll}
\text { 1. } & \text { Ho: }: \mu \mathrm{A}_{1}=\mu \mathrm{A}_{2} & \text { Нa }: \mu \mathrm{A}_{1}>\mu \mathrm{A}_{2} \\
\text { 2. } & \text { Ho: } \mu \mathrm{B}_{1}=\mu \mathrm{B}_{2} & \text { Нa }: \mu \mathrm{B}_{1}>\mu \mathrm{B}_{2} \\
\text { 3. } & \text { Но }: \rho \mathrm{B}=0 & \text { Ha }: \rho \mathrm{B} \neq 0 \\
\text { 4. } & \text { Но }: \rho \mathrm{A}=0 & \text { На }: \rho \mathrm{A} \neq 0
\end{array}
$$

The test statistic used for hypothesis number 1 and 2 is real different test statistic(statistic $\mathrm{z} /$ statistics $\mathrm{t}$, depending on the distribution of data obtained). As for the hypothesis number 3 and 4 is the analysis statistic correlates to product moment [14] with the formula:

Remarks:

$$
r=\frac{\sum x y}{\sqrt{\sum x^{2} y^{2}}}
$$

1. $r=0$ then there is no relationship between the two variables

2. $r=(-1)$ then the relationship is very strong and is not unidirectional

3. $r=(+1)$ then the relationship is very strong and are unidirectional

In this study, analysis of product moment (r) is calculated using by SPSS 20.0. R value can not be compared directly, for example, we can not say that the value of $r=0.8$ is twice the value of $r=0.4$. Thus, the squared value of $r$ can measure precisely the ratio / proportion of certain factors and statistical 
value is called the coefficient of determination, $r^{2}$. The coefficient of determination can be defined as the value that states the proportion of $\mathrm{Y}$ diversity which can be explained/ described by a linear relationship between the variables $\mathrm{X}$ and Y [15].

\section{RESULTS AND DISCUSSION}

Data chemistry of students' learning outcomes is obtained by using the test results to learn the material of redox reaction in the form of data post test. While the data of students' motivation is obtained by the motivation questionnaires that given at the end of learning.

\section{Hypothesis 1}

Tabel 4. 1. Paired Samples Test

\begin{tabular}{|c|c|c|c|c|c|c|c|}
\hline \multicolumn{5}{|c|}{ Paired Differences } & \multirow[t]{3}{*}{$\mathrm{t}$} & \multirow[t]{3}{*}{ df } & \multirow{3}{*}{$\begin{array}{l}\text { Sig. } \\
(2- \\
\text { tailed })\end{array}$} \\
\hline \multirow[t]{2}{*}{ Mean } & \multirow[t]{2}{*}{$\begin{array}{c}\text { Std. } \\
\text { Deviatio } \\
\mathrm{n}\end{array}$} & \multirow[t]{2}{*}{$\begin{array}{l}\text { Std. } \\
\text { Error } \\
\text { Mean }\end{array}$} & \multicolumn{2}{|c|}{$\begin{array}{c}95 \% \\
\text { Confidence } \\
\text { Interval of the } \\
\text { Difference } \\
\end{array}$} & & & \\
\hline & & & Lower & Upper & & & \\
\hline 2,333 & 8,880 & 1,621 &,- 982 & 5,649 & 1,439 & 29 & ,161 \\
\hline
\end{tabular}

Based on the calculation of the second hypothesis sig = $0.161>0.05(\alpha)$ which means that the results of student learning that learned through guided inquiry learning model together with the direct learning instruction which both use exelearning media.

\section{Hypothesis 2}

Tabel 4.2. Paired Samples Test

\begin{tabular}{|r|c|c|c|c|c|c|c|}
\hline \multicolumn{9}{|c|}{ Paired Differences } & t & df & $\begin{array}{c}\text { Sig. } \\
(2- \\
\text { Mean }\end{array}$ & $\begin{array}{c}\text { Std. } \\
\text { Deviatio } \\
\mathrm{n}\end{array}$ & $\begin{array}{c}\text { Std. } \\
\text { Error } \\
\text { Mean }\end{array}$ & \multicolumn{2}{c|}{$\begin{array}{c}\text { 95\% Confidence } \\
\text { Interval of the } \\
\text { Difference }\end{array}$} & & & & \\
\cline { 4 - 6 } & & & Lower & Upper & & & \\
\hline 700 & 12,377 & 2,260 & $-3,922$ & 5,322 &, 310 & 29 &, 759 \\
\hline
\end{tabular}

Based on the calculation of the second hypothesis sig = $0.759>0.05(\alpha)$ which means the motivation of students that learned through guided inquiry learning model together with the direct learning instruction which both use eXe learning media.

\section{Hypothesis 3}

Tabel 4.3. Correlations

\begin{tabular}{|c|c|c|c|c|}
\hline & & & Motivasi & Hasil_belajar \\
\hline \multirow{6}{*}{$\begin{array}{l}\text { Spearman' } \\
\text { s rho }\end{array}$} & & $\begin{array}{l}\text { Correlation } \\
\text { Coefficient }\end{array}$ & 1,000 &, $843^{* *}$ \\
\hline & Motivasi & $\begin{array}{l}\text { Sig. (2- } \\
\text { tailed) }\end{array}$ & & ,000 \\
\hline & & $\mathrm{N}$ & 30 & 30 \\
\hline & & $\begin{array}{l}\text { Correlation } \\
\text { Coefficient }\end{array}$ &, $843^{* *}$ & 1,000 \\
\hline & Hasil_belajar & $\begin{array}{l}\text { Sig. (2- } \\
\text { tailed) }\end{array}$ & , 000 & \\
\hline & & $\mathrm{N}$ & 30 & 30 \\
\hline
\end{tabular}

**. Correlation is significant at the 0.01 level (2-tailed).

The third hypothesis is based on the calculation value of $r$ $=0.843$, which means there is a significant correlation between motivation and learning outcomes of students that learned through guided inquiry learning model with exelearning media.

\section{Hypothesis 4}

Tabel 4.4. Correlations

\begin{tabular}{|ll|r|r|}
\hline & & Motivasi & Hasil_belajar \\
\hline \multirow{4}{*}{ Motivasi } & Pearson Correlation & 1 &, $828^{* *}$ \\
& Sig. (2-tailed) & &, 000 \\
& $\mathrm{~N}$ & 30 & 30 \\
Pearson Correlation &, $828^{* *}$ & 1 \\
Hasil_belajar &, 000 & 30 \\
& Sig. (2-tailed) & 30 & \\
**. Correlation is significant at the 0.01 level (2-tailed).
\end{tabular}

The third hypothesis is based on the calculation value of $r$ $=0.828$, which means there is a significant correlation between motivation and learning outcomes of students that learned through direct learning model intruction with exelearning media.

\section{Discussion of Results}

In this study chemistry learning media usage by applying the guided inquiry learning model to see increased motivation and student learning outcomes.

After learning the material redox reaction, then do the test / implementation of the two groups of classes, experiment 1 and experiment-2 has been tested homogeneity and normality. Then the average values obtained chemical postest the experimental class- 1 and experiment 2 at SMA Al Hidayah Terrain amounted to 83.00 and 80.67 , not much different. In addition, the learning motivation questionnaire was also given to the student experiment class- 1 and- 2 at the end of the experiment of learning to see the motivation to learn and be taught using student responses after chemical instructional media that have been prepared and validated by experts.

Based on the results of students' learning motivation questionnaire calculation of the experimental class-1 to be more motivated than 2nd class experiments to study the chemistry lesson. It ditujukkan with an average value of students' learning motivation questionnaire experimental class-1 with an average of 50.67 is higher than in the experimental class-2 which has an average value of 49.97 .

Results of learning and motivation of students that learned through guided inquiry learning model did not differ significantly with direct learning instruction which both use eXe learning media. Factors affecting the improvement of student learning outcomes is the role of media that much support or theoretical understanding of the issues contained in 
the evaluation. Chemistry learning media on redox reactions more emphasis on active learning, creative, fun, and can be accessed offline. In chemistry developed learning media is equipped with simulations of matter that has feedback so as to provoke the motivation of students. Thus the implementation of learning can be done in a fun yet still learning objectives achieved well.

Then proceed to test the correlation to see if there is a correlation between motivation on student learning outcomes through guided inquiry learning model with exelearning media. Based on data from the results obtained from the output correlation table it is known that the level of significance of 0.000 which shows that there is a significant correlation between the variables $\mathrm{x}$ (independent) to variable $\mathrm{y}$ (dependent) criteria $(0.000<0.05)$ means that the model significantly correlated. So the conclusion is $\mathrm{Ha}$ accepted. Then also continued to test the coefficient of determination to see the influence of students' motivation to learn the results they get and what percentage of influence. R-square value level or also known as the coefficient of determination was $r$ square $=0.710$ which shows that the independent variable (motivation to learn) contributed $71 \%$ to the dependent variable (the learning outcomes). The rest is (100-71)\% influenced by other factors.

Furthermore, the last hypothesis test. Hypothesis test results showed that there was a significant correlation between motivation and learning outcomes of students that learned through direct instruction models with exelearning media that have criteria $(0.000<0.05)$ means that the model significantly correlated. So the conclusion is $\mathrm{Ha}$ accepted. Then also continued to test the coefficient of determination to see the influence of students' motivation to learn the results they get and what percentage of influence. R-square value level or also known as the coefficient of determination was $r$-square $=$ 0.685 which shows that the independent variable (motivation to learn) contributed $68 \%$ to the dependent variable (the learning outcomes). The rest is (100-71)\% influenced by other factors.

\section{CONCLUSION}

Based on the results of research and discussion, we can conclude that: there is a difference in student learning outcomes that learned with the model of guided inquiry and direct intruction which both use media exe learning; there is no difference in student learning outcomes that learned with the model of guided inquiry and direct intruction which both use exe learning media; there is a correlation between motivation and learning outcomes that learned through guided inquiry learning model with media Exe Learning; and there is a significant correlation between motivation and learning outcomes of students that learned throughlearning model the Direct Instruction with media Exe Learning.

\section{REFERENCES}

[1] G. Atmaja, Mahmud, R. Silaban, and Z. Muchtar, "Analysis of the Teaching and Learning in Chemistry Class X Vocational High School Academic Year 2015/2016," Universitas Negeri Medan, Medan, Proceedings of the $1^{\text {st }}$ AISTEEL, pp. 388-394, 2016.

[2] C. Gormally, P. Brickman, B. Hallar, anda N. Amstrong, "Effects of Inquiry-based Learning on Students'Science Literacy Skills and Confidence," International Journal for the Scholarship of Teaching and Learning., in press.

[3] Suminah, "Peningkatan Motivasi Belajar Ipa Dengan Model Pembelajaran Inquiry Pada Siswa Kelas III SDN Pasucen 02," Surakarta, Muhammadiyah University of Surakarta, 2014.

[4] S. Siregar, "Pengaruh Model Pembelajaran Inkuiri Berbasis Media Animasi Terhadap Pemahaman Konsep, Sikap Ilmiah Dan Assesmen Kinerja Siswa Pada Konsep Sintesis Protein,” Jurnal EduBio Tropika, Vol 1, Edisi Khusus, pp. 60-100, Desember 2013.

[5] A. Silalahi, "Philosophical Pespectives that Describe How The Work In Chemistry Education," Universitas Negeri Medan, Medan, Proceedings of the $1^{\text {st }}$ AISTEEL, pp. 319-328, 2016.

[6] Sardiman, "Interaksi dan Motivasi Belajar Mengajar," Raja Grafindo Persada, Jakarta, 2014.

[7] J.M. Keller, Motivational design of Instruction. In C. M. Reigeluth, (Ed.), "Instructional-design theoris and models: An overview of their current status," Hillsdale, NJ: Lawrence Erlbaum Associates, 1983.

[8] R. Trinora, "Hubungan Motivasi Belajar Dan Hasil Belajar Siswa," Jurnal FKIP Universitas Lampung, Bandar Lampung, 2015.

[9] R. D. Suyanti, Strategi Pembelajaran Kimia, ed. 1, Graha Ilmu: Yogyakarta, 2010.

[10] Saptorini, "Peningkatan Keterampilan Generik Sains Bagi Mahasiswa Melalui Perkuliahan Praktikum Kimia Analisis Instrumen Berbasis Inkuiri," Jurnal Inovasi Pendidikan Kimia, Vol 2, No 1, hlm 190-198, 2008.

[11] Warjana, and R. Abdul, "Membuat Bahan Ajar Berbasis Web dengan eXe,” Elexmedia Komputindo, Jakarta, 2009.

[12] S. Saragih, “Aplikasi SPSS Dalam Statistik Penelitian Pendidikan," Perdana Mulya Sarana, Medan, 2015.

[13] S. Arikunto, "Prosedur Penelitian Suatu Pendekatan Praktik," Rineka Cipta, Jakarta, 2006.

[14] Algifari, "Statistika Deskiptif Plus," (ed. revisi Cetakan kedua) UPP STIM YKPN, Yogyakarta, 2013.

[15] I. S. Peers, "Statistical Analysis for Education and Psychology Researchers," London, The Falmer Press, 1996. 
